\title{
Bir Bilim İnsanının Kavramlarla Yolculuğu: İlhan Tekeli ve Alternatif Bir Patika
}

\author{
Nihal Ekin Erkan ${ }^{1}$ \\ ORCID: 0000-0003-2557-7116
}

\author{
Çiğdem Aksu Çam² \\ ORCID: 0000-0001-6328-1290
}

\author{
Zeynep Arslan Taç3 \\ ORCID: 0000-0002-5260-0054
}

\section{Öz}

Bu makalede bilim insanlarının bilgi üretim sürecinde kullandıkları kavramların yeri ve önemi, bir bilim insanı olarak Prof. Dr. İlhan Tekeli'nin kavramlarla olan ilişkisi üzerinden ele alınmıştır. Kavramlar, sosyal bilimcilerin toplumsal gerçekliği anlama ve açıklama uğraşısinda temel dayanakları, araçlarıdır. Tekeli'nin kavram oluşturma serüveni, bilim insanlartnın dünyanın düşünce macerasının bir parçası olmak ve bilimsel olanı gündelik hayata taşımak iddiaların sorgulamak için bir vaka çalışmasına olanak verecek nitelik ve kapsamdadır. Bu nitelik ve kapsamı ortaya çıkaran, Tekeli'nin Türkiye kent ve bölge planlama alanının kurucularından biri olarak önerdiği kavramlarla alana yön vermekte etkili olmasından ziyade, kavramları epistemolojik sorgulamalarla ele almasıdır. Çalışmada Tekeli'nin kent çalışmaları alanında oluşumuna katkı sunduğu çok sayıda ve çeşitteki kavramı içeren geniş kavram setinden iki örnek incelenmiştir. Örnek olarak seçilen "yönetişim" ve "konut sunum biçimi" kavramları üzerinden Tekeli'nin kavram oluşturma serüveni kesitlerle tasvir edilmiştir. Araştırmada çeşitli veri toplama teknikleri ve analiz stratejilerini bir araya getiren karma yöntem kullanılmıştır. Benimsenen karma yöntem içinde verilerin bulgulara dönüştürülmesinde katılımo nesneleştirme ve söylem analizi belirleyici olmuştur. Çalışma bulgularıyla bir bilim insanının bilimsel bilgi üretimi sürecinde kavramlar aracılı̆̆ılyla özgün katkı geliştirme olanakları tartışmaya açılmış ve Tekeli'nin kavramlarla ilişkisinde alternatif bir patika oluşturduğu belirlenmiş̧tir.

Anahtar Kelimeler: İhan Tekeli, kent çalışmaları, kavram oluşturma, yönetişim, konut sunum biçimi.

\footnotetext{
${ }^{1}$ Prof. Dr., Marmara Üniversitesi, E-mail: nekin@marmara.edu.tr

2 Dr. Öğr., Üyesi, Adana Alparslan Türkeş Bilim ve Teknoloji Üniversitesi, E-mail: caksu@atu.edu.tr,

${ }^{3}$ Arş. Gör., Marmara Üniversitesi, E-mail: zeynep.arslan@marmara.edu.tr idealkent @ Kent Araştırmaları Dergisi (Journal of Urban Studies) 


\title{
A Scientist's Journey with Concepts: İlhan Tekeli and an Alternative Path
}

\author{
Nihal Ekin Erkan 4 \\ ORCID: 0000-0003-2557-7116
}

\author{
Çiğdem Aksu Çam 5 \\ ORCID: 0000-0001-6328-1290
}

\author{
Zeynep Arslan Taç 6 \\ ORCID: 0000-0002-5260-0054
}

\begin{abstract}
This article discusses the position and the importance of the concepts used in the process of scientific knowledge production basing on an analysis of Prof. Dr. Illhan Tekeli's relation with concepts as a scientist. Concepts are the main tools for social scientists to grasp and explain social reality. Ilhan Tekeli's journey of concept building as a social scientist is portrayed to present an exemplar to scientists being a part of the world's shared ideas and claiming to convey scientific facts to everyday life. Tekeli not only guided the field of urban studies by presenting new concepts and conceptualizations as one of the founders of the field of urbanism in Turkey but also engaged in epistemological interrogation on concepts of the field. Two samples among the set of broad-spectrum of concepts that Tekeli contributed to the development of urban studies are examined. Tekeli's adventure of concept building is portrayed through analyzing his contribution to the concepts of "governance" and "mode of housing provision". The study applies mixed-method as the research method to combine various forms of data collection techniques and analysis strategies. Participatory objectification and discourse analysis are conducted for converting data into findings within the mixed method. The opportunities for developing authentic contributions of a scientist to the scientific knowledge production process through concepts are opened for discussion basing on the findings of the study. It has been argued to conclude that Tekeli has developed an alternative path with regards to his relations with concepts.
\end{abstract}

Keywords: Ilhan Tekeli, urban studies, concept formation, governance, mode of housing provision.

\footnotetext{
4 Prof. Dr., Marmara University, E-mail: nekin@marmara.edu.tr

${ }^{5}$ Asst. Prof., Adana Alparslan Türkeş Science and Technology University, E-mail: caksu@atu.edu.tr,

${ }^{6}$ Research Asst., Marmara University, E-mail: zeynep.arslan@marmara.edu.tr idealkent @ Kent Araştırmaları Dergisi (Journal of Urban Studies) 


\section{Giriş}

Kavramlar, sosyal bilimcilerin toplumsal gerçekliği anlama ve açıklama uğraşısında temel dayanakları, araçlarıdır. Sosyal bilimler alanının "sözlere" doğrudan ve muazzam etkiler atfedilerek inşa edilen bir alan niteliği gösterdiği hatırlanacak olursa, alandaki gelişimde bilim insanlarının kavramlarla ilişkisinin önemi daha açıklık kazanır. Sosyal bilimciler, kavramları kullanarak dilsel bir üretim sürdürürler. Üretim araçları olarak kavramlara olan hakimiyetleri, yaşadıkları toplumu ve zamanı etkileme ve değiştirme çabalarını doğrudan etkiler. Kavramlara sahiplilik biçimleri, içinde bulundukları dönemin ve ortamın bilgi üretim tarzıyla doğrudan bağlıdır.

Yirminci yüzyılın ilk yarısında bilimsel bilgi üretiminde kavramlar, zihinde temsil nesneleri olarak işlev görmekteydi. Zira bu dönemde, Tekeli'nin (2019) belirttiği gibi bilimsel bilgi üretimi temsili kuramlar çerçevesinde yürütülüyordu. Ağırlıkla pozitivist nitelikli bu kuramlarda; sosyal gerçekliğin kavramlar yardımıyla zihinde nesnel olarak temsil edilebileceği kabul edilerek, evrensel geçerlilik iddiası taşıyan nesnel bilgi üretimi amaçlanıyordu. Bununla birlikte 1980 'li yıllarda post-modern ve post-yapısalcı eleştirilerle nesnellik tartsşması yükseldiğinde iki eğilim ortaya çkar. İlk eğilimde mutlak öznelci yaklaşımla bilimsel bilgi üretiminin olanaksızlı̆ı üzerine yoğunlaşılınca, kavramlar referans değerini kaybeder. İkincisinde eleştirel gerçeklik içinde hermonotik temelli kavramlar özneller arası uzlaşmanın, oydaşmanın sağlanacağı ya da sağlanması gereği üzerinde durulan birimler olmaya doğru evrilir. Sonuç olarak, kavramlar üzerinde anlaşma sağlanamazsa Neuman'ın da $(2009$, s.82) ifade ettiği şekliyle, "insanlar kavramlara dair terimleri ve tanımlarını paylaşmazsa bir değeri olmaz.".

Dolayısıyla her koşulda, sosyal bilimlerde kavramların varlığı hem bu alandaki bilimsel faaliyeti mümkün kılar, hem de ister özneller arası isterse mutlak öznellik savunulması olsun epistemik topluluğun iletişimini sağlayacak ana birimler olarak vazgeçilmez işlevlerini sürdürür. Sosyal bilimler, kavramlarda uzlaşmaya ve kavramların paylaşımına dayalı ortaklık temelli bir üretim alanı olarak nitelenebilir.

Bu üretim alanı Bourdieu'nun (2016) akademi için ifade ettiği gibi, rakibin aynı zamanda müşteri olduğu bir alandır. Benzer şekilde kavramlar, bir yandan üretim sürecinin araçlarıyken, öte yandan sosyal bilimcinin yaratım sürecinin ürünleri olur. Buradaki yaratıcllk, gerçekliği etkileme ve değiştirme potansiyelini barındırır ve bu potansiyeli geliştirir. Bu potansiyelin bilim insanlarının deneyimiyle bağını kurmak ve kavramları gündelik hayat akış 
performanslarına taşımak için günümüzde henüz gelişmekte olan temsili olmayan kuramlar önemli bir olanaktrr. Thrift (2008) temsili olmayan kuramların varlık temelli değil, oluşan/olan temelli olduğunu vurgular (Vannini, 2009). Bu kuramların oluşan/olan temelli niteliğiyle, birlikte yaşam deneyimi içinde ifade biçimi kazanması dolayısıyla kuramdaki kavramlar da dinamikleşir. Bu durumda önemli olan kavramlar değil, kavramsallaştırma olur. Temsili olmayan kuramların gelişmeye başlamasının kavramlara yaklaşımımızda ne tür değişiklikler ortaya çıkaracağı günümüzde henüz araştırılmayı beklemektedir.

Bu makalede temsili olmayan kuramların gelişmesini Türkiye'den takip eden bir bilim insanının, Prof. Dr. İlhan Tekeli'nin, kavramsallaştırma serüveninden kesitler sunularak böyle bir araştırmaya giriş için adım atılmaktadır. Makalede bir bilim insanını nesneleştirerek kavramlarla ilişkisine dair bilgi üretimi yoluyla, hem kavramlara dair ilgi toplamak ve anlayış geliştirmek, hem de çalışmaları izlenerek İlhan Tekeli'nin kavramlarla yolculuğuna tanıklık etmek amaçlanmıştır. Tekeli'nin kavram oluşturma serüveni, bilim insanlarının dünyanın düşünce macerasının bir parçası olmak ve bilimsel olanı gündelik hayata taşımak iddialarını sorgulamak için bir vaka çalısmasına olanak verecek nitelik ve kapsamdadır. Bu nitelik ve kapsamı ortaya çıkaran, Tekeli'nin Türkiye kent ve bölge planlama alanının kurucularından biri olarak önerdiği kavramlarla alana yön vermekte etkili olmasından ziyade, kavramları epistemolojik sorgulamalarla ele almasıdır. Makalede konu, Prof. Dr. İlhan Tekeli'nin kavramlarla olan ilişkisi, bu ilişkinin Türkiye kent (yerleşim) çalışmaları alanı ile etkileşimi ve alana kazandırılmasında önemli rolü olan kavramlardan seçilen örneklerle ele alınmaktadır.

\section{Karma Araştırma Deseni}

Tekeli'nin kavramsallaştırma serüveninin tasvirinin kendisinin altmış yıla yakın bir sürede çok çeşitli konularda yüzü aşkın kitap, altı yüz elli kadar makale üretmiş olması nedeniyle hem niceliksel hem niteliksel açıdan güç olduğu açıktır. Bununla birlikte Tekeli'nin kavramsallaştırma deneyimi, Türkiye kent çalışmalarındaki katılımclar için kavramlar üzerinden ortak bir deneyime/oluşa davetiye çıkarmakta, bir firsat yaratmaktadır. Bu makale bu daveti kabul etme sorumluluğu üstlenerek kaleme alınmıştır. Sorumluluğun yerine getirilmesi, daha ileriki çalışmalarda, şehircilik alanının kavramlarla düşünme pratiğinin içinde kolektif olarak ve performatif şekilde sağlanabilir. 
Bunun için alandaki katılımcların iletişim, iş birliği, eleştirel düşünce ve yaratıcılık yetilerini kullanması hem olanaklı hem zorunludur.

Makalede sunulan vaka çalışmasında, çeşitli veri toplama ve analiz stratejilerini birleştiren karma araştırma deseni (Biesta, 2017) kullanılmıştır. Üçü makalenin yazarı olmak üzere, dört katılımcının yer aldığı veri toplama teknikleri arasında derinlemesine görüşme ve doküman taraması öne çıkmıştır. Dokümanter taramada, kişisel dokümanlardan ve ilgili politika metinlerinden yararlanılmıştır. Kişisel dokümanlar Ekin Erkan'ın Tekeli ile görüşmelerine ait 1990'lı yılların başından itibaren sistematik olarak derlediği notlarıdır. Notlar arasında telefon görüşmeleri, toplantı tutanakları, tartışma notlarının üzerine işlendiği makaleler bulunmaktadır. Kişisel dokümanlar katılımcı nesneleştirme (Bourdieu, Wacquant, 2007) metodu benimsenerek söylem analizine (Fairclaough, vd 2011) tabi tutulmuştur.

$\mathrm{Bu}$ analiz sonucunda Tekeli'nin Türkiye kent çalışmaları alanına kazandırdığı ya da içerik değişimine katkı sunduğu kavramlarının çeşitlenerek bir kavram seti oluşturduğu saptanmıştır. Kavram setinin içinde, "kentleşme" ve "kentlileşme" gibi alanın anahtar kavramları yanı sıra özgün niteleme olarak "imar operasyonu" ve "azman sanayi şehri" kavramları, sivil toplum alanının iskeletini oluşturan ve STK'lar kısaltmasıyla anılan "sivil toplum kuruluşları" gibi her biri çeşitli açılardan özgünlük taşıyan kavramlar bulunmaktadır. Bu geniş yelpazeden örnek olarak iki kavram seçilmiştir: "Yönetişim" ve "konut sunum biçimi". Söz konusu kavramların seçilmesinin nedeni, bu iki kavramın Tekeli'nin kavramsallaştırma serüveninin deneyimsel olarak analizini destekliyor olmasıdır. Her iki kavramda da düşünümsel olan, eylemsel olanla ilişkilenmiş, Tekeli'nin gündelik hayat pratiği içinde oluşan/olan temelli olarak yaşam deneyimi içinde ifade biçimi kazanmış ve evrilmiştir.

Örneklemdeki kavramlarla ilgili Tekeli'nin eserleri yanı sıra karşılaştırmalı analize olanak verecek şekilde uluslararası alan yazın taranmıştır. Ek olarak Yükseköğretim Kurulu tez veri tabanı taranmıştır. Çalışmanın omurgasını oluşturan, odak konusu kavramlar olarak belirlenerek gerçekleştirilmiş olan üç derinlemesine görüşmenin ilk ikisi 2013 yılında, sonuncusu içinde bulunduğumuz 2020 yılında gerçekleştirilmiştir. İlk iki görüşme TÜBİTAK tarafından 101K406 numara ile desteklenen Şehir Çalışmalan Alanında Kavramlar Haritası ve Tarihi başlıklı araştırma projesi kapsamında Burcu Temiz ve Nihal Ekin Erkan tarafından yapılarak kayıt altına alınmıştır (Ekin Erkan, 2014). Görüşmelerdeki zamansal ara Tekeli'nin kavramlar odaklı düşüncesinin artzamanlı tespitini olanaklı kılmıştır. Tekeli'nin kavramsallaştırma sürecine dair anlatısında tekrar eden deseni ve farklılıkları, dolayısıyla evrimi çıkarmak mümkün 
olmuştur. Farklı dönemlerde gerçekleştirilen görüşmeler karşılaştırılarak bilimsel bilgide geçerlilik ve güvenilirlik ölçütlerinin niteliksel araştırmadaki karşılığı olan tutarllık ölçütü sağlanmıştır. Dolayısıyla hem nicel hem nitel veri kullanılarak, bir bilim insanı olarak İlhan Tekeli'nin kavramsallaştırma serüveni kısıtlı bir çerçevede tasvir edilebilmiştir.

\section{Kavramlarla Yolculuk Başlıyor}

Tekeli kavramlar konusunda ihtiyaç ve farkındalığının gelişmesinde 1960'lı yıllarda Nusret Hızır'dan felsefe dersleri almasının etkili olduğunu belirtir. Pozitivizmin doğrulanabilirlik ilkesinin değiştirilmesi gerektiğini belirten Hans Reichenbach'ın asistanlığını yapmış olan Nusret Hızır'ın katkısıyla kavramlarda soyut-somut ilişkisini çözümlemesi mümkün olmuştur. Somuttan soyuta gitmenin kolay, asıl zorluğun soyutu somuta dönüştürmekte olduğunu, bu uğraşının alternatifli bir süreç olduğunu deneyimlemiştir. Bu deneyimde, soyutu somuta taşırken herkesin farklı önermeler geliştirebilmesinin yaratıcılığa alan açtığın keşfetmiştir. Bu durum sayesinde bilgi üretiminde kuramsal boyuta geçişi mümkün olmuş ve bu geçişte kapıyı aralayan kavramlar olmuştur. Tekeli kavramların düşünümsel pratiğiyle bilginin kuramsal üretimini yakalamış ve bu üretime henüz 1964 yllında ilk makalesinin yayınlanmasıyla katılmıştır. Kavramlarla olan ilişkisinde başlangıçta kurulan bu epistemolojik yaklaşımı günümüze dek sürekliliğini korumuştur. Bir sosyal bilimci olarak sosyal dünyaya dair gizli olan bulmak, sorgulamak ve aktarmak (Bauman, 2010) konusunda tükenmeyen merak ve hayret duygusunu, Deleuze ve Guattari'ye (1992, s.38) göre "felsefeye, yalnzzca felsefeye ait olan kavramlarla" yakalamış, plancı sorumluluğuyla etkinleştirip günümüze dek korumuştur.

Felsefede kavramı sonsuz hızda işlem yapan düşüncenin eylemi olarak niteleyen Deleuze ve Guattari kavramların sosyal bilimlere ödünç verilmesine karşı dururlar ve şeylerin durumu ve koşulları ile uğraşan bilimin kavramlara gereksinimi olmadığın belirtirler. Kavramlar sosyal bilimler sistemine dahil olduğunda önermeler haline, yargılarla karışmayan önermeler haline dönüşür (Novak ve Gowin, 1984). Kavramlar, sahip olduğu yoğunlaşmayı yitirir. “Önermeler kendi gönderimleri aracılığıyla tanım kazanırlar ve gönderim de olayı değil ama şeylerin ve cisimlerin durumuyla bir ilişkiyi, aynı şekilde, bu ilişkinin koşullarını kapsar." (Deleuze ve Guattari, 1992, s.29)

Sosyal bilimlerin merkez eksenindeki ilişki düşünce ile görgül olan arasındaki ilişkidir. Düşüncenin görgül olan ile ilişkisinin kurulmasına dayanan 
üretimde yapılan, en sade haliyle olgu, terim ve atıf (tanım) üçlemesi üzerinde yükselen bir kavramsallaştırmadır. Gerring (2001) Ogden-Richards Üçgeni kullanarak bu kavramsallaştırma sürecini analitik hale dönüştürür. Farklı soyutlama düzeylerindeki her bir kavramı bu analitik şemada ayrıştırıp, zihnimizde tekrar bütünleştirebiliriz. Piaget'e göre (aktaran Vygotsky, 1998) “Bir zihinsel işlemin bilincine varmak demek, onu eylem düzleminden dil düzlemine aktarmak, yani onu sözcüklerle ifade edilmesini olanaklı kılacak biçimde düş gücünde yeniden yaratmak demektir." Ancak Vygotsky'nin (1998) bilimsel kavramların ve gündelik kavramların gelişmesi arasındaki ilişkiyi incelerken ortaya koyduğu gibi, "bir kavramın bilincine ve tasarlanmış bir denetime ancak bir sistemin parçası olduğu zaman tabi kılınabileceği, bize açık bir gerçek olarak gözükmektedir. Üst düzeyde bir kavram, alt düzeyde bir dizi kavramın varlığını gerektirir ve aynı zamanda farklı genellik düzeyleri arasında bir sıradüzeni öngörür. Dolayısıyla verilen kavram genellik ilişkilerinin oluşturduğu bir sistem içinde yer alır" (s.137). Sosyal bilimlerde genellik ilişkilerinin doğa bilimlerindeki netlik ve istikrardan yoksun olması alandaki kavramlara da şüphe ile yaklaşılmasına zemin hazırlar. Bu zemin sosyal bilimlerin metoda bağlılı̆̆ın ve metot testleriyle sınanmaya açık olmasını daha önemli hale getirir.

Uygulamalı bir bilim dalı olarak kent ve bölge planlama, geçerlilik ve güvenilirlik testini sadece bilimsel alanda değil, gündelik hayatta da sürekli vermek zorunluluğunu ve şansını taşıyan disiplinler arası bir düşünce ve eylem alanıdır. Bir planc kendisini farklı ontolojik kabulleri olan disiplinlerin kesişiminde konumlandırarak, "kuramsal bilginin sistemli bir biçimde eyleme uygulanması" (Friedman, 1987) sorumluluğunu üstlenir. Planlama alanındaki bir bilim insanını "bilim bilim içindir"den uzak tutan bu sorumluluk, aynı zamanda kavramlara olan ihtiyacını şekillendirir. Planlamada kavramlar, analizin sonuçlarını değiştirmeye yaraması için, Tekeli'nin ifadesiyle, "çifte kavrulmuştur". Plancilar kavramsal ve kuramsal açıdan "enlerle" ilgilenir, çifte uğraş verirler. Örneğin eleştirel kuramın önermelerini benimseyen bir plancı, kuramın temel önermesini, eleştirel kuramcıların, kuramı acil, pratik veyahut araçsal ihtiyaçlar için yardıma çağırma anlayışını reddetmelerini (Brenner, vd. 2014, s. 39) eleştirmek durumunda kalabilir. Bu, eleştirilenin eleştirisini yapmaktır. Aynı şekilde planlamada kavramlar soyutlama düzeyleri açısından "enler" arasındaki yelpazeye yayılır. Bir uçta henüz gerçekleşmemiş ve hatta düşünülmemiş olanı imleyen en soyut kavram, diğer uçta bu soyuttan korunmanın ya da bu soyutu hayata geçirmenin yolların çizen, nesnel olanı ele veren en somut kavram vardır. Tekeli'de kavram oluşturma, 
bu uçlarda gelgit yapan, düşünsel ile nesnel olan arasında bir aracı bulma çabası olarak anlaşlabilir. Çabası duyusal, duygusal, düşünsel olanın davranışsal hale bürünmesidir. Çalışmalarında kavramlar, kimi zaman temsili kuramlar çerçevesinde bir nesneyi etiketleyebilir, kimi zaman iletişimsel rasyonalite arayışında bir oydaşma birimine dönüşebilir. Ya da son yıllarda olduğu gibi temsili olmayan kuramlarda kolektif bir üretme ve öğrenme deneyimine karşılık gelebilir. Tekeli'nin yazılarına birçok yazarın genellikle yaptığı gibi, terim ve tanımı şeklinde başladığına tesadüf etmeyiz. Kuramsal çerçeveleri değişkenlik gösterse de Tekeli'nin çalışmalarında kavramlar her daim dinamik nitelik gösterir ve çatışmalı bir şekilde içeriklendirilir. Tekeli kavramları araçsal üstünlük kazanmak ve bilimsel alanın genişletip korumak için kullanur.

Makalede bu saptamalar Türkçe kentsel siyaset ve politika alanyazınına kazandırdığı "yönetişim" ve "konut sunum biçimi" kavramları örnekleriyle incelenmektedir. Her iki terim için de inceleme, terimlerin uluslararası yazındaki kavramsallaştırılmalarıyla başlamaktadır. Ardından Tekeli'nin getirdiği kavramsallaştırmanın uluslararası yazından ayrışan yanları ve özgün katkısının evrimi betimlenerek sınırları çizilmektedir. Son olarak, kavramsallaştırma deneyiminin alandaki etkileşim içinde nasıl bir oluş ortaya çkardığı tartı̧ılmaktadır. Sonuç bölümünde ise bilim insanlarının kavramsallaştırma serüvenine dair sorular sorulmaktadır. Ancak, makale sorularla bitmiyor, oluş devam ediyor.

\section{Yönetişim Kavramının Ortaya Çıkışı ${ }^{7}$}

Yönetişim kavramı, 1990'lı yıllardan itibaren siyaset bilimi, kamu yönetimi ve uluslararası ilişkiler disiplinlerinde küreselleşme tartışmaları çerçevesinde, değişen devlet-toplum ilişkilerini kavramak ve açklamak için kullanılır. Aslında kavram ilk olarak bilimsel bilgi üretimi süreçleri içerisinde ortaya konmamıştır. Yönetişimi ilk kullananlardan Dünya Bankası (1991), kavramı kendisinin temel faaliyet alanı doğrultusunda, ekonomik kalkınma ve büyüme için farklı ülkelerde desteklediği programların başarısını hedefleyerek yolsuzlukla mücadele gündemi doğrultusunda içeriklendirir ve siyaset, demokrasi ve katılımla ilişkisini de bu bağlamda kurar. Diğer taraftan, siyaset bilimi, kamu yönetimi, kent ve bölge planlama gibi disiplinlerde üretilen çalışmalarda "yönetişim", farklı anlamlar yüklenir; yazarların önceliklerine ve benimse-

\footnotetext{
${ }^{7} \mathrm{Bu}$ başlık altında sunulan yönetişim kavramının ortaya çıkışı ve kentsel siyaset alanındaki gelişiminin daha geniş bir kuramsal tartışması için bkz. Aksu Çam, 2017.
} 
dikleri yaklaşıma, çalışmanın odaklandığı konuya göre farklı olgular temelinde tanimlanir.

Bu disiplinlerde "yönetişim" yaklaşımı "devletin değişen rolü" argümanına dayanır. Yönetişim modelinde devlet artık, "kürekleri çeken" konumunda değil, "dümeni idare edendir". Yönlendiricilik rolünü üstlenir (Pierre, 2000). Tek taraflı olmaktan çıkan, yöneten ile yönetilen arasındaki keskin sınırların kalktı̆̆ı politika-yapma, karar-alma ve uygulama süreçlerini işaret eden yönetişim kavramı böylece farklı yazarlar tarafından "etkileşimli sosyo-politik yönetim biçimleri" (Kooiman, 2000), "sektörler arası ortaklıklar" (Waddell \& Brown, 1997), "kendi kendini örgütleyen ağlar aracılığıyla gerçekleşen toplumsal eşgüdüm biçimleri" (Rhodes, 2000), "aktörler arasında eşgüdüm ve uyum durumu" (Pierre, 2000) gibi ifadelerle tanımlanır. Tüm bu farklı ifadelerde sektörler (devlet-piyasa-sivil toplum) ve aktörler arası karşılıklılık ilişkisini ifade eden terimlerin kullanılması dikkat çeker: Etkileşim, ortaklık, eşgüdüm, uyum. Özetle, yönetişim tek taraflı yönetim biçimi yerine gücün farklı sektörler ve aktörler arasında dağıtılmış ve paylaşılmış olduğu bir yönetim sürecini ifade eder.

Diğer taraftan, Batı yazınında "kentsel yönetişim" kavramı, yönetişim kavramından farklı olguları işaret edecek şekilde içeriklendirilir. Çok-aktörlü, etkileşimli yönetim anlamında yönetişimin kullanımı kentsel yönetişim perspektifinden anlamlıdır. Bunun nedeni siyaseti yatay, enformel ilişki ağları temelinde işleyen bir süreç olarak kentsel kararların alınmasında müdahil olan aktörler temelinde okuyan (yeni) kurumsalcı geleneğin kentsel siyaset çalışmalarında köklü bir yeri olmasıdır. Bu geleneğin izleri kentsel siyasal gücün nasıl ve kimlerden oluştuğuna ilişkin seçkinci ve çoğulcu yaklaşımlarda, siyaseti himayecilik-kayırmacılık ilişkileri üzerinden okuyan çalışmalarda, "kentsel koalisyonlar" ve bunun devamı olarak nitelenebilecek 1980'lerin sonundan itibaren öne çlkan kentsel rejim analizinde sürülebilir. Böylelikle kentsel bağlamda yönetişim kavramı, 1990'lardan beri kentsel siyaset yazınında giderek merkezi bir konum edinir ve ulus-altı ölçekte işleyen yönetim modelinin yanı sıra, kentsel siyasal iktidarın büründüğü biçimi de ifade eder. Özellikle çok-katmanlı yönetişim kavramsallaştırması kent-bölge çalışmalarında öne çıkar (Peters ve Pierre, 2001). Bu kavram sadece farklı yönetim kademelerindeki kurumlar arasındaki ilişkileri değil, farklı kademelerde gerçekleştirilen yönetişim süreçleri arasındaki ilişkileri de kapsar. Kjaer ise yönetişimi, siyasal iktidarın merkezden yukarıya, ulus-üstü birimlere doğru ve aşağıya, yerinden yönetim birimlerine doğru hareket ederken aynı zamanda dışarıya doğru -küresel ve yerel sivil toplum aktörlerine- kayması şeklinde "oto- 
rite göçü" olgusuyla kavramsallaştırır (2009, s.138-9). Kentsel yönetişim bu bağlamda çıkar, politika ve stratejilerini, hiyerarşik yönetim kademelenmesi dışında, uluslararası ve ulus-üstü kademede savunma kapasitesine sahip ulus-altı ölçekte oluşturulan yönetişim (yönetim + ağ ilişkileri / ortalık / koalisyon / koordinasyon) modelini ifade eder. "Çok-katmanlı yönetişim" ya da "otorite göçü" olarak ifade edilen dönüşüm, yerindenlik ilkesiyle uyumlu olarak kent yönetimlerinin güçlenmesini içerir.

Diğer taraftan yönetişim, devlet-toplum-piyasa ilişkilerinde dönüşümü imleyen bir model olarak Marksist gelenekten gelen eleştirel şehirciler ve coğrafyacılar tarafından çok farklı olguları işaret edecek şekilde kavramsallaştırılır. Bu bağlamda kentsel yönetişim, 1970'ler sonrası yaşanan kapitalizmin kriziyle küresel düzlemde değişen toplumsal ve ekonomik ilişkilerin kentsel mekânı nasıl dönüştürdüğü, bu dönüşümün beraberinde getirdiği yeni krizler temelinde ele alınır. Çünkü kentsel olan, kapitalizmin çatışmalı ve sürekli değişen toplumsal ilişkileriyle ilgilidir. Harvey 1989 tarihli makalesinde bu dönüşümleri, 1970'lerin sonundan itibaren Keynezyen refah devletinin içine girdiği kriz sonucunda neoliberal ideolojinin kurumsallaşmasına paralel olarak, kentsel siyasetin hizmet sunumu ve yeniden dağıtıma odaklanan önceliğinin yerini şehre yatırım çekme, istihdam yaratma gibi amaçlarla kendini gösteren girişimci özelliğinin almasıyla açıklar. Devletin kamusal hizmet sunumu yoluyla gördüğü yeniden dağıtım işlevi yerini "girişimci" devlete bırakır. Kent yönetimlerinin bu yeni ekonomik işlevleri yerine getirmesiyse devletin mekânsal olarak yeniden yapılanmasıyla mümkündür. Bu yapılanma "devletin yeniden ölçeklendirilmesi" olarak kavramlaştırılır ve kentsel yönetişim süreci devletin yeniden ölçeklendirilmesinin temel mekanizmasıdır (Brenner, 2004). 1970'ler sonrası görülen küresel siyasal ve ekonomik dönüşümlerin etkisiyle ulusal devletin bazı düzenleyici yetkileri ve hakları yeniden ölçeklendirilir, bazıları doğrudan kent ölçeğiyle irtibat kurabilen Avrupa Birliği (AB) gibi ulus-üstü kurumlara, çoğunlukla gelir yaratıcı nitelikteki diğer bazı yetkilerse yerele, yerinden yönetim birimlerine aktarılır (Brenner, 2004; McCann, 2017, s.314). Kentsel yönetişimin mülki sınırları artık belediyeler gibi yerel yönetim kurumlarıyla sınırl değildir, bu durum kent-bölgeler ölçeğinde anlaşılmalıdır (McCann, 2017, s.316). Soja (2000), kent-bölgelerin oluşumunu çok-katmanll, bölgesel kentleşme süreci olarak tanımlar. Kentin bu şekilde yeniden tahayyülü, kentsel hizmetlerde çeşitlenme ve farklılaşma, yerel seçim sistemi tartısmaları, katılımcı yönetim, kentsel-mekânsal işlev dağılımının yeniden tanımlanması gibi kentsel yönetişimle ilgili meselelerin bölgesel ölçekte yeniden tanımlanması, yeni planlamaları ve politikaları gerektirir. Ulus- 
lararası yazında yönetişim ve kentsel yönetişim kavramlarının ortaya çıkmasıyla bu gereksinimler de tartışmaya açlmıştır. Türkiye'de ise yönetişim kavramı 1996 yllında İstanbul'da düzenlenen Birleşmiş Milletler İnsan Yerleşkeleri Konferansı (HABITAT II) gündemiyle beraber Türkçe kentsel siyaset yazınında yerini almıştır.

\section{Tekeli'nin Yönetişim Kavramına Verdiği Yön}

HABITAT II Konferansı, Türkiye'de demokratikleşme tartışmalarının yapıldığı, karar alma süreçlerinde temsili demokrasi aracılığıyla seçilen yöneticilerin ve teknokratların hâkim rolünün sorgulanmaya başladığı bir döneme rastlar. Yönetişim kavramı, böyle bir siyasal ve yönetsel tartışmanın gerçekleştirildiği bir bağlamda, Türkiye demokrasisi ve siyasetine ilişkin endişelerle Birleşmiş Milletler'in gelişmekte olan ülkeler için önerdiği governance modelinin örtüşmesiyle öne sürülür. Böylelikle yönetişim kavramı Türkçe alanyazında, Batılı governance kavramından farklı bir bağlamsal çerçevede gelişir (Aksu Çam, 2014, s. 209). Gerek içerden gerek dişardan seslendirilen demokratikleşme talepleri Türkiye'de yönetişim kavramının geliştiği tarihsel ve siyasal bağlamın temel meselesidir. HABITAT II Konferansı'na hazırlık çalışmalarında yer alanlar, yönetişim kavramını demokratikleşme bağlamında, özellikle katılımcı demokrasi ilkesini öne çıkararak içeriklendirir ve Türkçe'deki etkileşim sözcüğünde olduğu gibi karşılıklılığa yapılan vurgu ile Türkçeleştirirler.

Tekeli'nin yönetişim kavramını ele alışı ve içeriklendirmesi, kavramı gündemde tutan çok sayıda makale üretmesiyle, Türkiye alanyazınında, kentsel siyaset ve kentleşme deneyimi içerisinde belirleyici ve kurucu olmuştur. Tekeli, yönetişimin toplumu yönlendirmede sorumluluk dengesinin devletten sivil topluma doğru kaymasını işaret ettiğini ve hükümet dışı aktörleri de dahil eden bir yapı içerisinde demokratiklik, açıklık, hesap verme, çoğulculuk, kararın ilgililere en yakın yerde üretilmesi, yerindenlik gibi ilkeleri de kapsadığını belirtir. Yönetişimi, devlet-toplum arasında yeni bir ilişki biçimi olarak ele alır. Yönetişime geçiş sürecinde devlet artık işleri bizzat gerçekleştiren değil, yönlendirendir. Böylece Tekeli yönetişimi, tek özneli, merkezi ve hiyerarşik bir işbölümü içinde, araçsal rasyonelliği ön plana alan, yapan, üreten, bunun için kaynakları ve yetkileri kendinde toplayan eski yönetim modeline karşıt bir alternatif olarak, insan haklarına dayalı performans ölçütlerini gerçekleştiren, çok aktörlü, desantralize, ağsal ilişkiler ve iletişimsel bir rasyonellik anlayışı içinde, toplumdaki aktörleri etkin kılan, kaynakların yönlendi- 
rilmesini kolaylaştıran bir model olarak kavramsallaştırır (Tekeli, 1999, s. 247249).

Tekeli'nin kavramsallaştırmasının temel dayanağını "iletişimsel rasyonellik" oluşturur ve bu temelde bir yönetişim modelinde katılımcılık merkezi ilkelerden biri olmak durumundadır. Yönetişim kavramı HABITAT II günlerinden itibaren kent çalışmaları alanında bir oydaşma birimi olmaya aday şekilde sunulur. Ancak yeni bir kavram olarak birden ortaya çıması Türkiye kent çalışmaları alanında tepki oluşturur. Hem Türkçe dil yapısı açısından hem de içerik açısından dirençle karşllaşır. Kavram, Koselleck'in (2009) hareket kavramları nitelemesinde olduğu gibi Türkçe alanyazınında bir yandan geleceğin beklentileri doğrultusunda şekillenirken, diğer yandan kavramları kullananların sosyo-ekonomik yaşam koşullarından türeyen bilinç tutumları ile eleştirilir. Tekeli'nin yönetişimi kavramsallaştırma pratiği, Birleşmiş Milletler alanında temsili demokrasi teknisyenlerine karşı tetiklenir, yerelde kavramın demokratiklik talebinde bir araç işlevi görebilmesi için sürer. Tekeli'nin serüveninde kavram tam bir fikir birliğine varmayı değil, başlangıçtakinden daha fazla uyuşmayı sağlamakla bir oydaşma birimi olma niteliğini örnekler. Kavramin terim, tanım, olgu üçlemesindeki olgu esası, yine Tekeli'nin katk1sının olduğu İzmir örneğinde evrimleşir.

\section{Yönetişim Modelinin Hayata Geçmesi: İzmir Modeli}

İzmir Büyükşehir Belediyesi'nin 2017-2018 yıllarında Tekeli'nin danışmanllğında demokratik belediyecilik pratiğinin bir model oluşturacak şekilde kurumsallaştırılması amacıyla başlattığı çalışmalar "İzmir Modeli" olarak anılmaktadır. Model kapsamında gerçekleştirilen projelerin tasarlanma ve uygulanma süreçlerinde Tekeli'nin yönetişim kavramsallaştırmasında öne çkard1ğı ilke ve değerler benimsenmiştir. İzmir Modeli çalışmaları Tekeli'nin yönetişim kavramsallaştırmasının Türkiye koşullarına özgü bir yerel ölçekte somutlaştırılması, hayata geçirilmesi olarak değerlendirilebilir.

Aziz Kocaoğlu'nun on beş yıllık büyükşehir belediye başkanlığı pratiklerinin katılımcı yollarla geliştirilmesi ve modelleştirilmesi çalışması olarak nitelenebilecek İzmir Modeli'nin hedefi demokrasi açı̆̆ı sorunudur. Bu sorun, yerel demokrasi güçlendirilemeden çözülemez. "Halkın demokrasi talebini daha açı ve somut olarak formüle etmesi, başarılı demokratik yönetim örneklerine sahip çıkması gerekmektedir" (Tekeli, 2018a, s.13). Dolayısıyla, yerel demokrasinin güçlendirilmesi demokratik bir yönetişim modelinin geliştirilmesinin ön koşuludur. Tekeli, İzmir Modeli çalışmasını önemser. Model kap- 
samında gerçekleştirilen çalışmaların dayandığı temel kavramsal değerlerin spekülatif idealleştirmeler olmadığını, Kocaoğlu'nun model çalışmalarını önceleyen on beş yıllık belediye başkanlığı dönemindeki belediyecilik pratiklerinden yola çıkıldığını belirtir (Gürsel, 2020). Dolayısıyla İzmir Modeli olgusal gerçekliğe dayanmaktadır. Kocaoğlu belediyeciliğine ilişkin görgül olan normatif değerlere dönüştürülmüş, kuramsal temel kazandırılmış ve aktarılmiştır.

İzmir Modeli çalışmaları başlangıçta dört kavramsal hedef belirler: Yaşam kalitesi, katılımcılık ve yönetişim, yenilikçilik ve sürdürülebilirlik. "Katılımclık ve yönetişim", "yaşam kalitesi" hedefinin alt boyutlarından biridir, ona hizmet etmektedir. Bu hedeflere ulaşmak içinse kilit kavram katılımdır (Tekeli, 2018b, s.22). Tekeli, eski tarz yönetim ile yönetişim arasında ayrım yapar: "Yönetim karşısında yönetişimin gelişmesiyle, toplumun bireyleri kendilerine emrivaki halinde gelen kararlara uyum göstermeye zorlanmayacaktır. Yönetim halinde verilen kararlar karşısında yabancılaşmış birey, yönetişim halinde kendisinin alınmasına katıldığı kararlar karşısında, kendisini kamusal özne olarak görmeye başlayacak ve ona adanmışlık duygusuyla sahip çıkacaktır" (Tekeli, 2018a, s. 24). Merkezi ve hiyerarşik yönetim anlayışının ortaya çıkardığı iş bölümü terk edilerek, insanların birbirinin haklarına saygılı, yatay ilişkiler/ağ ilişkileri içinde bir yönetişim anlayışının ortaya çıkardığı yeni bir toplumsal iş bölümü kurulacaktır. "Bu yeni iş bölümünde, kendi gereksinimlerini ve önceliklerini algilayabilen, bağımsız karar alabilen ve eylemde bulunabilen, kendilerini ve başkaların yönlendirme kapasitesine sahip aktörlerin (sivil toplum kuruluş ve topluluklarının) ağırlıklı yeri olacaktır" (Tekeli, 2018b, s.22). Tekeli, böyle bir toplumsal yapıyı daha demokratik olarak değerlendirir.

Tekeli, İzmir Modeli kapsamında gerçekleştirilen çalışmalarda benimsenen katılımc yolu kuramsallaştırırken özellikle Habermas'ın iletişimsel rasyonellik ve kamusal alan tezlerine sıklıkla atıf yapar. Eski yönetim modelinin meşruiyet çerçevesi araçsal rasyonellik üzerine kuruluyken, yönetişim modelinde siyasal meşruiyet, insanların dahil edilmesine dayanan "müzakereci" ya da "katılıma" demokrasi kapsamında kurulur. Meşruiyetini insanların karar alma süreçlerine dahil edilmesinden alan demokrasi anlayışı güçlendikçe, yönetim kavramı yerini iletişimsel rasyonellikle temellendirilen yönetişim anlayışına bırakır. Bu değişim aynı zamanda yurttaş anlayışından, ağdaş anlayışına geçiş olarak da ifade edilebilir (Tekeli, 2018b, s. 21-211). İşte bu demokrasi anlayışı "kamusal alanda" gelişip serpilir: Yurttaşların ortak sorunları üzerine müzakere ettikleri kurumsallaşmış bir söylemsel etkinlik alanı (Tekeli, 2018b, s.117) bir nevi yönetişim kavramsallaştırmasının cisimleşmesidir. 
Habermas'in kamusal alan formülasyonu illa ki mekânsal bir alanı işaret etmez, ancak Tekeli İzmir Modeli çalışmasını aktardığı eserlerinde İzmir Büyükşehir Belediyesi'nin katılımc yöntemlerle gerçekleştirdiği mekânsal planlama çalısmalarını kamusal alan geliştirilmesi olarak değerlendirir ve demokratikleşme yolunda mekânsal kamusal alanların yerel yönetimler tarafından artırılmasını önemser. Bir toplumda kamusal alan ekonomik, kültürel ve toplumsal alanların tümünü kapsayacak şekilde genişletilebildiği ölçüde, o toplumda katılımcı demokrasinin ve yönetişimin başarılı bir şekilde hayata geçirilebildiği iddia edilebilir (s.23).

İzmir Modeli kapsamında gerçekleştirilen projelerde yaratıc katılım, kolektif yaratıcllk olarak nitelenen bir yöntem izlenir. Burada önemsenen husus, gerçekleştirilecek projenin -tasarım, planlama ya da tarımsal üretim faaliyetlerine ilişkin olsun- kolektif bir ürün olmasıdır. Ortaya çıkan eser / ürün, bir tasarımcı adıyla ya da icracı kurumun unvanıla değil, İzmirlilerin projesi olarak sunulmaktadır. Kolektifliğe yapılan vurgu İzmir ölçeğinde bir komünite yaratmakla ilgilidir. Yaratılması hedeflenen kolektif kent yaşamında ve yönetişiminde yerel yönetimin üstlendiği rolse katalizörlük olarak belirlenir. Bu rol Tekeli tarafindan, "belediyenin kendisini toplumdaki bireylerin yerine koymadan onların kalkınmaya katkılarını kolaylaştırmak" olarak tanımlanır. Büyükşehir Belediyesi bu rolü üç farklı faaliyet türüyle yerine getirebilir. İlki, temel kentsel altyapıları yapmak ve kentsel kamusal hizmetleri sunmaktır. Böylece, kentte yaşayanların üretim ve tüketim seçeneklerini arttırarak, onları "yaşam kalitelerini" geliştirmek konusunda özgürleştirir. İkinci olarak, İzmirlilerin üretim kapasitelerini geliştirmelerine yardımcı olmaktır. Son olarak, özellikle üreticilerin örgütlenmelerini sağlamaktır (Tekeli, 2018b, s.61). Böylelikle yönetişim kavramı soyut düzeyden somut düzeye faaliyetler şeklinde taşınmaktadır. Kavram soyut düzeyden somut düzeye doğru geçiş yapmaktadır. Bununla birlikte faaliyetlerin gerçekleşme düzeyi, olgunun ortaya çıkışının temel ölçüsüdür. Bu çalışmanın konusu dışında kalan bu ölçümü yapan araştırmalar geliştirilmeyi beklemektedir. Makalenin konusu ile sınırlı kalarak Tekeli'nin yönetişim kavramsallaştırmasının oluşa olanak veren şekilde evrimini sürdürdüğü belirtilebilir.

Özetle Tekeli'nin çalışmaları yönetişim teriminin Türkçe'deki evrimine eşlik eder, süreklilik taşır; kavramı çalışmalarında ülkenin içinde bulunduğu siyasal ve yönetim koşullarını analiz ederek ve tespit ettiği "demokrasi açığı" sorununun üstesinden gelmeye yönelik yeni bir siyaset yapma-yönetme anlayışı olarak içeriklendirir. Bu açıdan değerlendirildiğinde Tekeli'de yönetişim kavramı değer ve misyon yüklüdür. Yönetişimin merkezinde ülkenin 
demokratikleşme süreci ve süreçte karşlaşılan engelleri aşma talebi vardır. Tekeli' de demokratikleşme süreci "temsili demokrasinin" yarattı̆̆ pasif yurttaşlık sorununun aşılarak "müzakereci, "katılımc" demokrasi modellerine geçişi ifade eder. Yerel yönetimlerin, özellikle belediyelerin, katılımcı demokrasiye geçişte ve pekiştirilmesinde merkezi önemi vardır. Başarılı bir yönetişim modelinin geliştirilmesi ve kurumsallaştırılabilmesi katılımcılıktan ve güçlü yerelliklerin ortaya çıkabilmesinden geçer. Dolayısıyla Tekeli için güçlü yerel yönetimler demokratikleşme sürecinin en önde gelen aktörleridir. Sonuçta Tekeli'nin yönetişim kavramsallaştırması uluslararası yazındaki kavramsallaştırmalardan ve kullanımlardan ayrılır. Görgül olarak yönetimin / siyaset yapma biçiminin aldığı biçimi ya da bir neoliberal dayatmayı ifade etmenin ötesine geçer ve normatif bir değer yüklenir. Tekeli'nin bu yönetişim anlayışı İzmir Modeli çalışmalarında görgül olarak uygulanma olanağı da bulmuştur. Tekeli bir yandan kent çalışmaları alanında kavramı manipüle eder, diğer yandan sosyal gerçekliğe müdahale eder, bu müdahaleyi kent yöneticileri ve yaşayanlarıyla birlikte verme mücadelesi sergiler. Tekeli'nin yönetişim kavramı üzerinde süren çalışmalarıyla Türkiye kentsel siyaset alanına getirdiği açıım, kentleşme politikası alanı için henüz 1980'li yıllarda konut sunum biçimi kavramıla söz konusu olmuştur.

\section{Konut Sunum Biçimi Kavramının Yarattığı Olanaklar}

Konut, kent çalışmalarındaki birçok terim gibi, çok boyutlu bir olguya işaret eden, tanımlanması güç bir terimdir. Konut, hane halkı ve yaşadığı mesken arasındaki ilişkiyle sınırlı olmayıp daha geniş toplumsal çıarımlar içeren bir kavramdır (Kemeny, 1992). Konut hakkında düşünmek, çalışmak tek bir yöntem ya da yaklaşımla sınırlandırılmamıştır. Konut çalışmalarının özel bir disiplin odağı yoktur, bunun yerine sadece konutun kendisine odaklanır (King, 2017). Bununla birlikte konutun çok boyutlu yapısı, konut çalışmalarında başvurulan kavramların birbiri üzerinden açklanması, konutla ilişkili olarak tutulan verilerin veriyi tutan ülke veya kurumca farklı biçimlerde tanımlanıp, hesaplanması evrensel bir konut kuramı geliştirmeyi güçleştirmiştir. Yine de, genel bir konut kuramı geliştirmek mümkün olmasa bile konutla ilgili kuramlara ihtiyaç vardır (Ruonavaara, 2018). Konut çalışmalarının karşılaştığı bu güçlüğü aşmak için karşılaştırmalı konut çalışmaları oldukça önemlidir. Karşılaştırmalı konut çalışmaları iki veya daha fazla vakadaki benzerlikler, farklılıklar, eğilimler ve örüntüleri açıklamayı amaçlar. Bu bağlamda birçok ülke arasında konut sistemleri özelinde benzerlikler bulmaya odaklanabileceği 
gibi, izlenen farklı politikalara rağmen farklı ülkelerdeki benzer sonuçlara da odaklanabilir.

Konut sunumu, konut sunum yapısı, konut sunum biçimleri bir ülkenin konut sistemini, bu sistemin yapısını ve aktörlerini anlamak için günümüzde başvurulan temel kavramlardır ve güncel karşılaştırmalı konut çalışmaları yazınında da oldukça sık kullanılır. İngilizce alanyazında housing provision, mode of housing provision, structure of housing provision, form of housing provision şeklinde birbirinin yerine kullanılabilen kalıplar, aslında terimlerin ifade ettiği olguyu karşlayamasa da, yerine kullanılabilecek başka bir kavram da geliştirilememiştir.'Mode' of housing provision kavramı ilk kez 1983 yılında Michael Ball tarafindan yazılan Housing Policy and Economic Power: The Political Economy of Owner- Occupation kitabında kullanılır (Badcock, 2012). Ball, konut çalışmalarındaki vurguyu konut tüketiminden dağıtım ve bölüşüm zeminine taşımak ister ve konut sunum biçimil yapısını arsa geliştirme, bina üretimi gibi fiziksel süreçlerle birlikte konutun nihai kullanıcısına transferiyle ortaya çıkan konuta özel oturan (tenure) tipiyle ilişkili, tarihsel olarak belirlenmiş toplumsal ilişki seti, bu ilişkilerin bir ürünü olarak tanmmlar (Ball, 1983, s. 13-17). Konut sunu$\mathrm{mu}$, konut piyasasına çıarılan konut birim sayısı anlamına gelen konut arzından daha fazlasıdır. Konut sunumu yaşanılacak yerin fiziki olarak üretimi ile hâkim ekonomik çıkarların dahil olduğu toplumsal bir süreci kapsayan daha geniş bir anlamı içerir ve bu özelliği sebebiyle "konut sunumu" kavramı sıklıkla "konut arzı" kavramının yerine kullanılır (Türel, 2012).

Konut sunum biçimi kavramsallaştırması konut ve ekonomi arasındaki ilişki, konut ve kamusal alan tasarımı, konut politikaları ve konut sunumuna yönelik çok katmanlı karar-alma mekanizması, konut ve sağlık, eğitim gibi kamu politikaları arasındaki ilişki, sürdürülebilirlik ve ulaşılabilirlik, konut sınıfı gibi çok farklı bileşenleri kapsar. Diğer bir ifadeyle, konut sunum biçimleri kesişen ve karmaşık sosyal, ekonomik, siyasal ve kültürel ilişkileri içerir. Devlet, özel sektörün ya da kamu kurum ve kuruluşlarının araçlarıyla konut istek ve ihtiyaçların karşılamak amacıyla konut politikaları yoluyla konut sunumunu düzenleyebilir, konut sunum biçimlerine müdahale edebilir. Ülkelerin siyasal sistemlerine, refah rejimlerine, benimsediği konut politikalar1na ve ilgili diğer toplumsal süreçlerin tarihselliğine bağlı olarak ülkelerin konut sunum biçimleri birbirinden farklılık gösterir. Refah devleti ve konut sistemi ilişkisinden yola çıkılarak modellenen ideal-tipin farklı konut politikalarını açıklama ve sınıflandırmada yaşadığı güçlük, konut politikasının analizinde "konut sunumu biçimleri" kavramsallaştırmasıyla aşılmış, konut sunumu oynadığı bu kritik rolle ayrı bir politika alanı olarak özgünlüğünü de 
ortaya koymuştur (Bengtsson, 2012). Bengtsson konut çalışmalarında birçok araştırmacının konut politikalarına odaklandığını, ancak çok azının siyaset bilimi perspektifini benimseyerek, konut sunumuyla ilgili siyasal kurumlara ve karar-alma süreçlerine, elit ve yurttaş arasındaki etkileşim süreçlerine odaklandığını belirtir. Ona göre konut sunumu kavramsallaştırması, siyaset biliminin konut politikası ve siyaseti anlayışına ilişkin en belirgin katkıdır. Konut sunumu, politika (siyasa) alanı kadar siyaset alanının farklı düzey ve ölçeklerinde önemli kuramsal, özgün çıkarımlar sunar. Özetle, konut sunum biçimi kavramı uluslararası yazında konut meselesini anlamak, açıklamak ve dahası, müdahale yollarını işaret etmek için 1980'li yıllardan itibaren anahtar bir kavram niteliğini kazanır.

\section{Konut Sorununa Çözüm: Tekeli'den Kavram Önerisi}

Konut sunum biçimi kavramı, Türkiye'de 1981 yılında Kent-Koop tarafından düzenlenen Konut Sempozyumu'nda konut krizine çözüm arayışında Tekeli'nin kavramı sınırlı bir amaç için kullanmasıyla uluslararası yazından hemen önce ortaya çıkar. Türkiye'de Cumhuriyet'in kurulduğu ilk yıllardan itibaren ortaya çkan konut ihtiyacı ve bu ihtiyacın karşılaşmasına yönelik benimsenen politikalar neticesinde ortaya çıkan konut sorununun 1923-1950 döneminde kapsamlı olarak incelenmediğini, araştırılmadığını, 1965-1980 döneminde ise nüfus artışı, konut ihtiyacı ve kentleşme dinamikleri bağlamında tartışıldığını belirtmek mümkündür. 1980'li yıllara gelindiğinde konut sorunu tüm ülkeye yayılmıştır. $\mathrm{O}$ zamana kadar konut hakkında değil, konut üzerine yeterince düşünülmemiş ve konut sorunu bütünsel ve sistemsel bir yaklaşımla ele alınmamıştır. Aykıı bir örnek Tekeli tarafından Kapitalistleşme Sürecinde Türkiye'nin Konut Üretimine Bir Bakış adıyla 1978 yılında Mimarlık Dergisi'nin 16(1) sayısında yayınlanır8. Türel (1989), Türkiye'de Cumhuriyet'in kuruluşundan bu yana konut sunumundaki değişimlerin, özellikle sermaye birikimiyle ilişkili olarak Tekeli'nin, bu eserinde ortaya konduğunun altın çizer (s. 145).

Sonrasında, 24 Ocak 1980 kararları sonrası yaşanan ekonomik bunalımın konut sektörüne yansıması üzerine büyüyen konut sorununa çözüm arayışında Tekeli, bir bilim insanı olarak soruna müdahale etmeyi kolaylaştıran,

\footnotetext{
8 Tekeli'nin 1982 yılında yayınlanan değişik zamanlarda yazdığı farklı dergi ve kitaplarda yayınlanmış yazılarından oluşan Türkiye'de Kentleşme Yazıları kitabının içinde yer alan bu çalışmasına dair kitaptaki dipnotta yazının 1974 yılında yazıldığı belirtilmektedir.
} 
politika odaklı bir analiz birimi olarak konut sunumu kavramın kullanır. Kavram, konut sisteminde arz ile konut sunumunu birbirinden ayırır; konut sunumunun salt arzla ilişkili olmadığını ortaya koyar ve konut sorununu çok yönlü olarak tanımlar. 1982 yılında yayınlanan Konut'81 kitabında Türkiye'de Konut Kesiminde Ortaya Çıkmış Olan Değişik Konut Sunum Biçimleri altbaşlığıyla Tekeli'nin bir yazısı da bulunur. Yazı, konut sunum sisteminin hangi konut sunum biçimlerinin bir araya gelmesiyle oluştuğunu görebilmek için önce konut sunum biçimlerinin birbirinden hangi ölçütlere göre ayrıldığını açıklayarak başlar. Tekeli konut sunumu kavramsallaştırmasının merkezinde konut yapımındaki üç davranışsal birim bulunur: konut sahibi, girişimci ve devlet. Bu üç davranışsal birim arasında konut yapımına ilişkin işlevlerin bölüşümü konut sunum biçimini belirler. İşlev dağılımı aynı olsa bile bölüşümün farklı zamanlarda gerçekleşmesi sonucu değiştirebilir (Tekeli, 1982b, s. 61, 2009a, 2009b).

Tekeli konut sunum biçimi ifadesiyle, klasik ekonomi perspektifinin arztalep çözümlemelerinde ortaya çımmayan politika önerilerini kavramsallaştırmak için, toplum içinde konut çevresinde dönen ilişkileri adlandırdığını belirtir. Böylelikle başlangıçtan itibaren içerik olarak dinamik bir yapıya sahip olan konut sunum biçimi kavramı toplumsal ilişkilerin temsilini nesneler üzerinden yapar. Tekeli konut sunum biçimi kavramsallaştırmasının gücünü ve faydaların ilerleyen yıllarda, özellikle kent formunun tarihini yazmaya başladığında fark eder. Kentlerin kaynakların kıt olduğu dönemde tek tek binaların eklenmesiyle yağ lekesi şeklinde büyüme biçimine karşın, özellikle 1980'li yıllardan sonra kent parçası olarak adlandırılabilecek büyük parçaların eklenmesiyle büyümesini anlayıp, açıklamakta konut sunum biçimi kavramı önemli bir işlev kazanır. Kavram Tekeli'ye Türkiye kentleşme tarihinin yazılmasında, kentin büyüme dinamiğini yakalayan temel bir analiz çerçevesi kurar.

Kavram özellikle Türkiye kentleşme tarihi, mekânsal gelişim, konut politikalarıyla ilgili yazında yaygın olarak kullanılır. "Yapsatçı sunum biçimi", "toplu konut sunum biçimi", "ruhsatlı sunum biçimi", "alt gelir gruplarına konut sunum biçimleri", "sosyal konut sunumu", "spekülatif konut sunumu" gibi örneklerde görülebileceği gibi farklı bağlamlar için çoğaltılır ve kullanımı genişletilir. Konut sunumu ve konut sunum biçimi kavramı sadece 1980 sonrası izlenen konut politikalarıyla ilgili yazında değil, 1980 öncesi dönemi de kapsayan bir biçimde Türkiye'nin karşılaştı̆̆ konut sorunlarını, bu konut sorunlarını doğuran koşulları ve bu koşullara hangi aktörlerin hangi cevapları verdiğine yönelik inceleme ve araştırma çalışmalarında da kullanılır. Kavram, 
kentin formunu açklamakta ya da sosyal yapı ilişkilerini kurmakta elverişli bir araç haline gelerek evrimleşir. Konut sunum biçimleri coğrafi, tarihsel, kültürel koşullar içinde üretilir, bu sebeple zaman içinde değişir, yeniden tanımlanır, farklı coğrafyalarda farklı yapısal özelliklerle gerçekleşir. Tekeli'nin konut sorununa çözüm arayışında yararlandığı kavram önce soruna dair anlayışını geliştirmiş, sonra Türkiye kentleşmesine dair kavrayışını genişleterek dinamizmini sürdürmüştür. Türkçe kent çalışmaları alan yazınında yer eden kavram aynı zamanda politika metinlerine de girmiştir.

\section{Tekeli'nin Konut Sunum Biçimi Kavramsallaştırmasının Etki Menzili}

Güncel alanyazında konut sunumu ve konut sunum biçimi kavramlarının gelişmekte olan ülkelerin konut politikalarının tarihsel gelişimi ve durumunun analiz ve açıklanması ile karşılaştırmalı konut çalışmalarında kullanılmas1, Türkçe yazın ile uluslararası yazın arasındaki bütünlüğün korunması, alanyazının takibi ve hem yerel hem de uluslararası yazına katkı sunması nedenleriyle önemlidir. Konut sunum biçimi kavramının bir analiz çerçevesi olarak işlevselliği Türkiye kent çalışmaları yazınında birçok çalışmaya ilham kaynağı olmuştur. Bu bağlamda, öncelikle bilimsel bilginin yeniden üretiminin önemli bir basamağı olan lisansüstü tezlerde kavramın ayak izleri aranmiştır.

YÖK Başkanlığı tez veri tabanında tez adı ve tez özetini kapsayacak biçimde konut sunumuyla birlikte kullanılan konut arzı ve konut politikası kavramlarının ele alındığı tez çalışmaları taranmıştır. 1987-2019 yılları arasında on altısı doktora olmak üzere toplamda yetmiş lisansüstü tezde yukarıda belirtildiği şekilde konut sunumu kavramının kullanıldığı, yetmiş tezin on yedisinde ise doğrudan "konum sunum biçimi" kalıbının kullanıldığı; altmış dört tezde ise konut arzı kavramının kullanıldığı, tamamı şehircilik alanında üretilen dört tezde konut arzı ve konut sunumu kavramlarının tez ad veya özetinde birlikte kullanıldığı görülmüştür. Konut arzı kavramının ele alındığı tezler içinde ekonomi alanında yapılan üretimler önemli bir ağırlık taşımaktayken, konut sunum kavramının yer verildiği tezlerde ekonomi alanında yazılan tez yoktur. Hem konut arzı hem de konut sunumuyla ilgili daha geniş kullanımı olan konut politikası kavramının kullanıma ilişkin aynı kriterlerde arama yapıldığında yüz seksen dokuz tezin üretildiği görülmüsstür. Bu tezler içinde de on dokuzu, hem konut sunumu hem de konut politikası kavramlarına yer vermiştir. Konut sunum kavramına tez adı ve özetinde yer veren tezler başta Orta Doğu Teknik Üniversitesi (ODTÜ) olmak üzere on yedi farklı üni- 
versitede üretilmiştir. ${ }^{9}$ Tezlerin altmışı mimarlık ve şehircilik alanında, geri kalanlar peyzaj, kamu yönetimi, işletme, siyasal bilgiler ve sosyoloji alanlarında yazılmıştır. Yazılan tezlerin ikisi yabancı uyruklu öğrenciler tarafından Suriye ve Sudan konut politikalarının değerlendirilmesi üzerine hazırlanmış, yerel ölçekte konut sunum biçimleri analizi ve farklı ülke örneklerinin konut politikalarının karşılaştırılmasında kullanılmıştır. Konut arzı ve konut politikası kavramların ele alan tezlerin araştırma alanlarının ekonomi, endüstri mühendisliği, çevre mühendisliği, hukuk, sosyal hizmetler, ekonometri, inşaat mühendisliği, çalışma ekonomisi, maliye, bankacllık gibi daha geniş bir yelpazeye yayıldığı, konut sunum kavramının ise şehircilik ve mimarlık alanlarında yoğunlaştığı görülmüştür. 2016 yılında ODTÜ'den Prof. Dr. Ali Cengizkan ve The Royal Danish Academy of Fine Arts'dan Doç. Dr. Peder Deulund Mortensen'in ortak tez danışmanlığını yürüttügü Sosyal Konutun Geleceğini Güvenceye Almak: Alternatif Bir Yenilemeden Öğrenmek / Gyldenrısparken, Danimarka başlıklı doktora tezinde Nezih Burak Bircan "konut sunum biçimi" kavramının ilk olarak 1981 yılında İlhan Tekeli tarafından tanımlandığını ve ilgili akademik alanyazında farklı türdeki konut çözümlerini ifade etmek için yaygin olarak tercih ettiğini belirtir (Bican, 2016, s. 3).

Konutun disiplinler arası doğasında kabul gören bu kavramın kullanımı sadece tezlerle sınırlı kalmamış, Türkçe konut ve kentleşme yazınında sayılamayacak kadar çok inceleme ve araştırmada da konutun zaman içindeki değişim sürecini açıklamada başvurulan temel bir kavram haline gelmiş ve politika metinlerine girmiştir. Hükümetlere ekonomik ve toplumsal kalkınma konularında yardımcı olan Devlet Planlama Teşkilatı (Keleş, 2010, s. 391), bugünkü adıyla Cumhurbaşkanlığı Strateji ve Bütçe Başkanlığı planlarda konut sorunların tanımladıktan sonra politika önerilerinde bulunur ve uyulması gereken ilke ve hedefleri belirler. Bu nedenle, politika metni olarak Kalkınma Planları ve Özel İhtisas Komisyon Raporları incelenmiştir. 1993 yılında Devlet Planlama Teşkilatı Yedinci Beş Yıllık Kalkınma Planı hazırlıkları kapsamında kurulan Konut Özel İhtisas Komisyonu Gecekondu Alt Grubu'nun hazırladığı rapor Alt Gelir Gruplarma Konut Sunum Biçimleri ve Gecekonduda Dönüşüm başlığını taşır. 1999 yılında hazırlanmaya başlayan Sekizinci Beş Yıllık Kalkınma Planı Konut Özel İ̉tisas Komisyonu Raporu'nda da konut sunumu, Tekeli'nin kullandığı anlam ve çizdiği çerçeve ve yaptığı sınıf-

\footnotetext{
${ }^{9}$ Bu üniversiteler; Yıldız Teknik Üniversitesi, İstanbul Teknik Üniversitesi, Dokuz Eylül Üniversitesi, Gazi Üniversitesi, Ankara Üniversitesi, Mimar Sinan Üniversitesi, Karadeniz Teknik Üniversitesi, Çukurova Üniversitesi, Boğaziçi Üniversitesi, Gebze Yüksek Teknoloji Üniversitesi, İstanbul Üniversitesi, İstanbul Şehir Üniversitesi, İstanbul Bilgi Üniversitesi, Maltepe Üniversitesi, Selçuk Üniversitesi’dir.
} 
landırma bağlamında kullanılmıştır. Raporda konut sunum politikasının başarılı olması için konut kredisi, konut üretimi, konut yatırımı ve arsayı imara açma katsayısı ölçütleri belirlenmiş, kooperatif konut yoluyla konut sunumu, yap-sat sunum biçimi, ruhsatlı konut sunum biçimi kalıplarına yer verilmiştir (T.C. Başbakanlık Devlet Planlama Teşkilatı, 2001). Dokuzuncu Beş Yıllık Kalkınma Planı, Yerleşme Şehircilik Özel İhtisas Komisyonu raporunda "yap-satç", büyük ölçekli yapı firmaları türü üretimlere referans veren sunum biçimlerine ek olarak, yerel toplulukların güçlendirilmesi ve yerel toplumsal gruplar için firsat oluşturulması amaciyla ödenebilir konut sunumunu vurgulamıştır (T.C. Başbakanlık Devlet Planlama Teşkilatı, 2007). On birinci Kalkınma Planı Konut Politikaları Özel İhtisas Komisyonu ve Kentsel Yaşam Kalitesi Özel İhtisas Komisyonu Raporlarında konut sunumu biçimi seçilmiş ülkelerin konut sistemlerinin ve Türkiye'de genel durumun analizinde konut sunum biçimleri ve değişimler şeklinde kullanılmıştır (T.C. Kalkınma Bakanlığı, 2018b, 2018a). Raporlarda ayrıca, konut sunumu ve konut sunum biçimi konut pazarına çıkarılan, üretilen konut sayısını, Tekeli'nin sınıflandırdığı konut sunum biçimlerini kapsayacak ve üstüne genç ailelere hitap edecek kiralık sosyal konut gibi sosyal çeşitliliği de içeren anlamda kullanılmıştır. Kentleşme Şura'sında ise etkin konut sunum sistemleri, konut gereksinimini karşılamada yapılabilir ve kalıcı konut politikası oluşturmanın temel bileşeni olarak ele alınmış, kâr amacı gütmeyen konut sunumu, herkes için yeterli, sürdürülebilir, yaşanabilir ve hakça konut sunumu konut politikalarına yönelik temel hedefler arasında yer almıştır (T. C. Bayındırlık ve İskan Bakanlığı, 2009).

Konut sunum biçimi kavramsallaştırması, bu makalenin yazarlarının yer aldığı güncel bir araştırma projesinde de analiz çerçevesinin kurucu unsuru olarak kullanılır. TÜBITAK tarafından desteklenen 114K778 numaralı Türkiye'de Kentsel Konut Rejimi: Yapı, Aktörler ve Değişim başlıklı projede, Tekeli'nin konut sunum biçimleri kavramsallaştırması uluslararası yazınla ilişkilendirilir. Kentsel rejim analizine dayalı bir saha araştırmasını kapsayan projede konut sunum biçimleri, kentsel rejim analizine olanak verecek anahtar bir kavramsallaştırma olarak kullanılır. Adana kenti örneğinde 1950-2015 yıllarını kapsayan araştırmada görgül olarak tespit edilen bulgular, konut sunum biçimleri kavramsallaştırması kullanılarak yapı-aktör ilişkisi analizine tabi tutulur ve Bengtsson'un ifadesiyle "konut siyaseti" kapsaminda değerlendirilir (Aksu Çam, 2018).

Konut sunumu biçimi kavramının karar alıcılar için bir araç haline dönüşmesinde saptanan performansı, bilimsel alandaki performansıyla paralel- 
lik gösterir. Gerring'in (2001) kavram oluşturmada belirlediği ölçütlere göre değerlendirildiğinde, kavram tutarlılıkla kendini dıştakilerden (örneğin komşu kavram olarak konut arzından) farklılaştırır, açıklamada işlevsellik ve geçerlilik taşır, alanda yüksek kullanılabilirliğe sahiptir ve görgül araştırma tasarımı için uygundur. Bu özellikleriyle konut sunumu kavramsallaştırması Türkiye kent çalışmaları alanında bir mihenk taşıdır. Kavram, kent çalışmalarının diğer disiplinlerin ürettiği kavramları tüketen konumundan kavram üreten konumuna doğru evrilmesinde pay sahibidir, alanın gelişimine katkı sağlamıştır. Kavramın Tekeli'deki kullanım deneyiminin geçirdiği evrim, kavram oluşturmanın devingen niteliğini gözler önüne serer. Bu evrimin merkezinde, Türkiye kentleşmesi bağlamında Tekeli bulunmakla birlikte, uluslararası alanyazında Tekeli yer almamaktadır. Eşzamanlı kavramsallaştırmaya karşın Tekeli'nin katkısı uluslararası yazına ulaşmamıştır.

\section{Sonuç Yerine: Sorularla Devam}

Çalışmanın başlangıç soruları, gelinen bu noktada -makalenin sonunda- yanıtsız araştırma soruları olarak ortada durmaya devam eder: Bir bilim insanının bilgi üretim sürecinde kavramların yeri nedir? Bir bilim insanı kavramlarla ilişkisini nasıl kurar? Ödünç kavramlar yerine özgün kavramlar nasıl oluşturulur? Bu oluşum nasıl bir evrim geçirir? Bir bilim insanı olarak, dünyada akan büyük verinin içinde bir kod (veri) olmayı aşmamızda kavramların yeri nedir? Kavramlar bilim insanlarına ne vaat eder? Kavramlar alternatif patikalar yaratmamıza aracılık edebilir mi? Alternatif patikayı uygun ve uygulanabilir kılan nedir? Alternatif oluşturmakta işbirliği neden ve nasıl önemlidir? Dayanışmanın şartlarını anlamaktan uzaklaşmadan, bilimsel alanda özne olmak olası midır?

Bu makalede bir bilim insan olarak İlhan Tekeli'nin Türkiye kentsel siyaset ve politika alanında oluşumunda belirleyici olduğu iki kavramın "yönetişim" ve "konut sunum biçimi" kavramlarının- izi sürülmüştür. İki kavram örneğinde Tekeli'nin kavramlarla olan ilişkisi tasvir edilmiştir. Bu ilişki felsefe, sosyal bilim ve planlama alanlarından beslenir ve kuramsal arayışla bağı hiç kesilmemiştir. Tekeli'nin arayışında kavramlar kimi zaman düşünce, son zamanlarda eylem araçları olmuştur. "Kuram hevesinin peşinden giderken, bu hevesi indirgemeci ve sadeleştirici çerçevelerle beslememeye dikkat etmek lazım; yapılması gereken şey, daha ziyade, hem düşünce hem de eylem için yeni sorular ve ufuk doğuran kavramlar ve yöntemler bulmaktır." (Brenner, vd., 2014, s.157). Nitekim Tekeli'nin kullandığı kavramların 
dinamik ve çatışmalı yapısı yeni sorular üretimini desteklemiştir. Kavramlardan doğurttuğu sorularıyla kimi zaman yeni bir anlayış geliştirmiş, kimi zaman gerilim üretmiştir. Düşünsel yolculuğu yazılarının eşliğinde kesintisiz olarak devam etmiştir. Tekeli'nin yolculuğu bugün geldiği aşamada, kavramları yazılarında ve gündelik hayatında kolektif bir deneyime dönüştürmeye yönelmiştir.

Dünyanın farklı toplumlarında olduğu gibi toplumumuzda da bilimsel bilgi üretimi tarihsel koşullara özgü ve güç ilişkileri, ağlar dolayısıyla gerçekleşir. Türkiye'de kent çalışmaları alanında kavramlara dayanan epistemik bir topluluk henüz oluşmamıştır. Tekeli kent çalışmaları alanında kavramların bu epistemik topluluk oluşumunda anahtar bir işlevi olacağını belirtir. $\mathrm{Bu}$ yöndeki çalışmalarını üniversite, meslek odası, sivil toplum kuruluşları gibi çeşitlenen kurumlarda ve adına kurulan İlhan Tekeli Şehircilik Kültürü Vakfi'nda katkıda bulunarak, üreterek, direnerek, dünya düşünce macerasının parçası kalarak sürdürür.

Tekeli dünya düşünce macerasının bir parçası olmasına karşın, yıllar önce yaptığı tercihle uluslararası ağlar içinde bulunmak yerine, duygusal etki faktörünün hüküm sürdügü ulusal alanda kalmış ve Tekeli'nin eserleri ylllar içinde Türkiye'de üretim ve atıf yoğunluğunda bir dügüm noktası oluşturmuştur. Bu açıdan değerlendirildiğinde Tekeli seçimleri, çalışmalarında kullandığı kavramlar, kavramlarla ilişkisi ve kavramsallaştırma evrimiyle alanyazında ve gündelik hayatta alternatif bir patika yaratmıştır. Bu patika, ana akımdan ayrılır, özgün tırmanışlar barındırır; diğer yandan araştırmacılara yeni düşünsel olanaklar, takip edilecek izler sunar. Tekeli bu alternatif patikayı, dünyadaki bilimsel bilgi üretimini takip ve transfer ederken oluşan sorulara özerk yanıtlarını önceleyerek ve yeni sorular sorarak olanaklı kılmıştır. Tekeli'nin yanıtlarının ve yeni sorularının daha çok ve daha nitelikli eleştirilmesi, kavramsallaştırmalarının yaygınlık ve özgünlük etkisini arttıracaktır. Tekeli'nin kavramlarla ilişkisi, kavramsallaştırmanın öneminin ve gücünün kavramlara içkin olmadığını, asıl önemli olanın kavramlarla dünyayı anlaşıır kılmak ve değişimini tetiklemek olduğunu gösterir. 


\section{Extended Abstract}

\section{A Scientist's Journey with Concepts: İlhan Tekeli and An Alternative Path}

\author{
Nihal Ekin Erkan \\ ORCID: 0000-0003-2557-7116
}

\author{
Çiğdem Aksu Çam \\ ORCID: 0000-0001-6328-1290
}

Zeynep Arslan Taç

ORCID: 0000-0002-5260-0054

This paper discusses the position and the importance of the concepts used in the process of scientific knowledge production basing on an analysis of Prof. Dr. İlhan Tekeli's relation with concepts as a scientist. Concepts are the main tools for social scientists to grasp and explain social reality. As social sciences is a field built by attributing direct and immense power of influence to "words", the significance of scientists' relation to concepts in the development of the field becomes more clear. Social scientists, by using concepts, are involved in a linguistic production process.

The article aims to develop an understanding of knowledge-building processes by objectifying a scientist's relation with concepts. İlhan Tekeli's journey of concept building as a social scientist is portrayed to present an exemplar to scientists being a part of the world's shared ideas and claiming to convey scientific facts to everyday life. Tekeli not only guided the field of urban studies by presenting new concepts and conceptualizations as one of the founders of the field of urbanism in Turkey but also engaged in epistemological interrogation on concepts of the field. The paper attempts to depict Tekeli's relation to concepts and interaction of this relationship with the field of urban studies by focusing on two selected concepts presenting Tekeli's significant contribution to the process of conceptualization. Tekeli's experience of concept building is therefore interpreted through analyzing his contribution to the concepts of "governance" and "mode of housing provision".

The study applies mixed-method to combine various forms of data collection techniques and analysis strategies. In-depth interviews and docu- 
ment analysis are the primary data collecting techniques used in the study. Document analysis covers personal documents and policy papers. Personal documents mostly consist of notes taken systematically and personally by Ekin Erkan during her interviews with Tekeli since the 1990s. Participatory objectification and discourse analysis are conducted on documents to convert data into findings within the mixed method.

The first concept portrayed through Tekeli's work is "governance". Tekeli constantly refers to the term governance throughout his scientific and linguistic production and his works accompany the evolution of the term governance in Turkish. He conceptualizes the term as a new approach of governing and making politics that would be capable of overcoming the "democratic deficit" that he asserts as the most significant problem of Turkey considering the political and governmental conditions of the country. Tekeli thus attributes value and mission to the term governance. Valueloaded conceptualization of governance indicates the demand for democratization and overcoming any barriers to democratization. For Tekeli, the process of democratization requires a transition to "deliberative" and/or "participative" models of democracy, by which the problem of passive citizenship generated by "representative democracy" would be overcome. Local governments, more precisely municipalities, are central to this democratization process oriented towards participatory democracy. Strong localities and participation are required to develop a successful and institutionalized model of governance. Tekeli thus prioritizes strong local governments as the most significant actors of the democratization process. The conceptualization of governance by Tekeli differs from the conceptualizations and uses of the term in international literature. Empirically, it goes beyond pointing out a particular form of governing/making politics or expressing a neoliberal imposition; governance, as it is conceptualized by Tekeli, is loaded with normative values. This understanding of governance had the opportunity to be applied empirically in the Model of İzmir studies during Mr. Kocaoğlu's last term of mayoralty in İzmir in 2017 and 2018. On the one hand, Tekeli manipulates the concept of governance as it is conceptualized in the field of urban studies, on the other hand, he intervenes in the social reality. This intervention takes, in fact, a form of struggle in cooperation with local politicians, city managers, and inhabitants.

Secondly, this paper analyzes and tracks the evolution of the concept of "mode of housing provision", which Tekeli introduces to the field of urban studies in Turkey in early 1980 to induce a new perspective in the percep- 
tion and understanding of the housing problem in Turkey. Housing provision, structure of housing provision, modes of housing provision are the main concepts to grasp the structure and actors of the housing system in a given country. Those concepts are widely used in comparative housing studies in the international literature. The concept of mode of housing provision is first used in 1983 in a book entitled "Housing policy and economic power: The political economy of owner-occupation" by Michael Ball in international literature. Ball defines mode of housing provision as a production of a set of historically determined social relations associated with a tenure type that incorporates physical processes to the final occupier of the house. A mode of housing provision thus refers to a much wider social reality than housing supply, which would be simply expressed by numbers of housing units. The concept of mode of housing provision is introduced to the Turkish context by Tekeli during the Housing Symposium organized by Kent-Koop in 1981, just before it emerged in international literature, as a key that might offer a new perspective to deal with the housing crisis in Turkey. Tekeli starts to conceptualize the mode of housing provision by identifying the criteria to distinguish one mode of housing provision from another. Tekeli identifies three behavioral units that are central to the conceptualization of mode of housing provision: the owner, the entrepreneur, and the state. It is the distribution of functions related to housing construction among those behavioral units that determines the mode of housing provision. Tekeli discovers the strength and benefits of the concept of modes of housing provision when he attempts to write the history of urban form in Turkey. The concept offers a basic framework for analysis to grasp the dynamics of urban growth in depicting the history of urbanization in Turkey. The concept of mode of housing provision is widely used in the Turkish context, especially in the studies focusing on the history of urbanization, spatial expansion, and housing policies. The concept evolves as a helpful tool to explain the urban form or to link relations amongst social structures. Modes of housing provision are produced within geographic, historic, and cultural conditions. They, therefore, change in time, are redefined, and occur with different structural features in different geographies.

The paper concludes by stressing the alternative path Tekeli builds and follows in scientific knowledge production in the field of urban studies by engaging in concept building and reconceptualization processes to point out peculiar dynamics and phenomena of urbanization in Turkey. His work constitutes a nodal point combining scientific production and references in 
the field of urban studies. His path differs from the mainstream featuring unique climbs; on the other hand, it offers researchers new intellectual possibilities and traces to follow. Tekeli made this alternative path possible by prioritizing its autonomous responses to questions that emerge while following and transferring the scientific knowledge produced at the international level and by generating new questions. Any qualified criticism addressing Tekeli's questions and answers will increase the dominance and authenticity of his conceptualizations. Tekeli's relation with the concepts shows that the importance of conceptualization is not inherent to the concepts; it resides in its power to make the world more understandable and to trigger the change.

\section{Kaynakça/References}

Aksu Çam, Ç. (2014). Yönetişimin Türkçe serüveni. N. Ekin Erkan (Ed.), Şehir kavramlarını yolculuğu içinde (197-241). İstanbul: İdeal Kültür.

Aksu Çam, Ç. (2017). Kentsel siyasetin yeni sloganu: yönetişim. Şehir ve Toplum, 8,31-39.

Aksu Çam, Ç. (2018). Kentsel konut rejimi: yapı, aktörler ve değişim. Yayınlanmamış proje raporu, TÜBİTAK. 29.04.2020 tarihinde https://trdizin.gov.tr/ publication/show/pdf/project/TVRnd016azU= adresinden erişildi.

Badcock, B. (2012). Mode of housing provision. International Encyclopedia of Housing and Home içinde (s. 122). Elsevier.

Ball, M. (1983). Housing policy and economic power. London and New York: Methuen \& Co.

Bauman, Z. (2010). Sosyolojik düşünmek. Çev. A. Yılmaz, İstanbul: Ayrıntı Yayınları.

Bengtsson, B. (2012). Housing politics and political science. D. Clapham, W. A. V. Clark, ve K. Gibb (Eds.), The SAGE handbook of housing içinde (s. 206-229). Sage Publications.

Bican, N. B. (2016). Securing Future of social housing: learning from an alternative reneration/ Gyldenrisparken in Denmark. Orta Doğu Tenik Üniversitesi.

Biesta, G. (2017). Karma yöntemler. (Çev. E. Büyüköksüz) , eğitimde araştırma yöntemleri ve metodojileri, Arthur, J, Waring, M, Coe, R., Hedges, L. V. Çev. A. Erözkan ve E. Büyüköksüz, Ankara: Anı Yayıncllık, s. 241-251.

Bourdieu, P. (2016). Akademik aklnn eleştirisi: Pascalca düşünme çabaları. İstanbul: Metis Yayınları.

Bourdieu, P., Wacquant, L. J., (2007). Düşünümsel bir antropoloji için cevaplar. Çev. N. Ökten, İstanbul: İletişim Yayınları.

Brenner, N. (2004). Urban Governance and the production of new state spaces in Western Europe, 1960-2000. Review of International Political Economy, 11(3), 447-488.

Brenner, N., Marcuse, P., ve Mayer, M. (2014). Kar için değil halk için eleştirel kent teorisi ve kent Hakkı. Çev. Ali Yağız Şen, İstanbul: Sel Yayıncılık.

Deleuze, G., ve Guattari, F. (1992). Felsefe nedir?, Çev. Turhan Ilgaz, İstanbul: YKY. 
Dünya Bankası. (1991). Managing development: the governance dimension (A discussion paperno:34899).

http://www.ds.worldbank.org/external/default/WDSContentServer/WDSP/IB/20 06/03/07/000090341_20060307104630/Rendered/PDF/34899.pdf

Ekin Erkan, N. (2014). Şehircilik kavramlarının yolculuğu, İstanbul: İdealkültür.

Fairclough, N., Mulderring, J. and Wodak, R. (2011). Critical discourse analysis. Dijk, van T. A. (Ed.), Discourse Studies: A multidisciplinary introduction (357-378). 2nd edition. London: Sage Publications.

Friedmann, J. (1987). Planning in the public domain: from knowledge to action. Princeton University Press.

Gerring, J. (2001). Social science methodology: A criterial framework. Cambridge: Cambrige University Press.

Gürsel, E. (Mülakat yapan) ve Tekeli, İ. (Mülakat yapılan). (2018). Şehir hepimizin: konuk: İlhan Tekeli [Mülakat transkripsiyonu]. Medyascope TV web sitesi üzerinden 16 Aralık 2020 tarihinde https:/medyascope.tv/2018/12/24/sehir-hepimizinizmir-modeli-prof-ilhan-tekeli-ile-soylesi/ adresinden erişildi.

Harvey, D. (1989). From managerialism to entrepreneurialism: The transformation in urban governance in late capitalism. Geografiska Annaler. Series B, Human Geography, 71(1), 3-17.

Keleş, R. (2010). Kentleşme politikası (11. baskı). Ankara: İmge Kitabevi.

Kemeny, J. (1992). Housing and social theory. London and New York: Routledge.

King, S. (2017). Thinking on housing: words, memories, use. New York: Routledge. https://doi.org/10.1080/14036096.2017.1366935

Kjaer, A. M. (2009). Governance and the urban bureaucracy. Davies J. S. ve Imbroscio, D. L. (Ed.), Theories of urban politics. London: Sage Publications.

Kooiman, J. (2000). Societal governance: Levels, modes, and orders of social-political interaction, Pierre, J. (Ed.), Debating governance. Oxford: Oxford University Press.

Koselleck, R. (2009). Kavramlar tarihi politik ve sosyal dilin semantiği ve pragmatiği üzerine araştırmalar (A. Dirim, Çev.). İstanbul: İletişim Yayınları.

McCann, E. (2017). Governing urbanism: Urban governance studies 1.0, 2.0 and beyond. Urban Studies, 54.2, 312-326.

Neuman, W. L. (2009). Toplumsal araştırma yöntemleri: Nitel ve nicel yaklaşımlar: 1. cilt. Yayın odasi.

Novak, J. D. and Gowin, D. B. (1984). Learning how to learn. Cambridge: Cambridge University Press.

Peters, B. G. and Pierre, J. (2001). Developments in intergovernmental relations: towards multi-level governance. Policy \& Politics, 29(2), 131-135.

Pierre, J. (2000). Introduction: Understanding governance. In Pierre J. (Ed.), Debating Governance (1-13). Oxford: Oxford University Press.

Rhodes, R.A.W. (2000). Governance and public administration. Pierre J. (Ed.), Debating Governance (54-91). Oxford: Oxford University Press. 
Ruonavaara, H. (2018). Theory of housing, from housing, about housing. Housing, Theory and Society, 35(2), 178-192. https://doi.org/10.1080/14036096.2017.1347103

Soja, E. (2000). Postmetropolis: Critical studies of cities and regions. Oxford: Basil Blackwell.

T. C. Bayındırlık ve İskân Bakanlığı. (2009). Kentleşme Şurası 2009 - Kentsel Dönüşüm, Konut Ve Arsa Politikalarn Komisyonu Raporu. Ankara. http://www.kentges.gov.tr/_dosyalar/sura_raporlari/kitap3.pdf

T.C. Başbakanlık Devlet Planlama Teşkilatı. (2001). Sekizinci beş yıllık kalkınma planı konut özel ihtisas komisyonu raporu. Ankara.

T.C. Başbakanlık Devlet Planlama Teşkilatı. (2007). Dokuzuncu kalkınma planı (20072013) yerleşme-şehirleşme özel ihtisas komisyonu raporu. Ankara.

T.C. Kalkınma Bakanlığı. (2018a). On Birinci Kalkınma Planı (2019-2023) Kentsel Yaşam Kalitesi Özel İhtisas Komisyonu Raporu. Ankara.

T.C. Kalkınma Bakanlığı. (2018b). On Birinci Kalkınma Planı (2019-2023) Konut Politikaları Özel İhtisas Komisyonu Raporu. Ankara.

Tekeli, İ. (1978). Kapitalistleşme süreci içinde Türkiye'nin konut üretimine bir bakış. Mimarlik, 16(1), 34-38.

Tekeli, İ. (1982a). Türkiye'de kentleşme yazıları. ekonomik ve sosyal araştırmalar:3. Ankara: Turhan Kitabevi.

Tekeli, İ. (1982b). Türkiye'de konut sunumunun davranışsal nitelikleri ve konut kesiminde bunalım. Konut' 81 içinde (s. 57-101). Ankara: Kent-Koop.

Tekeli, İ. (1999). Modernite aşılırken siyaset. Ankara: İmge Kitabevi.

Tekeli, İ. (2009a). Konut sorununu konut sunum biçimleriyle düşünmek. İstanbul: Tarih Vakfi Yurt Yayınları.

Tekeli, İ. (2009b). Türkiye'nin konut tarihine konut sunum biçimleri kavramını yaklaşmak. Konut Sempozyumu içinde (s. 283-297). İstanbul: TMMOB Mimarlar Odası İstanbul Büyükkent Şubesi.

Tekeli, İ. (2018a). Sorularla İzmir modeli. İzmir: Dinç Matbaa.

Tekeli, İ. (2018b). İzmir modeli. İzmir için demokratik bir belediyecilik önerisi. II. Kitap. İzmir. Dinç Matbaa

Tekeli, İ. (2019) Temsili olmayan kuramların gelişimi planlama anlayışımızda ve kente bakışımızda ne tür değişmeler yaratıyor, Efil Journal, 2(7), 8-37.

Thrift, N. (2008). Non representational theory; space, politics, affet, London: Routledge.

Türel, A. (1989). 1980 sonrasında konut üretimindeki gelişmeler. ODTÜ Mimarlık Fakültesi Dergisi, 9(1), 137-154.

Türel, A. (2012). Konut arzı. In M. Ersoy (Ed.), Kentsel Planlama Ansiklopedik Sözlük (s. 291). İstanbul: Ninova Yayınları.

Vannini, P. (2009). Nonrepresentational theory and symbolic interactionism: shared perspectives and missed articulations. Symbolic interaction, 32(3),282-286. doi:10.1525/si.2009.32.3.282. 
Waddell, S. and Brown, D. L. (1997). Fostering intersectoral partnering: A guide to promoting cooperation among government, business, and civil society actors. Institute for development research (IDR) reports no.13.3. http://commdev.org/files/ 1305_file_fostering_intersectoral_partnering.pdf

Wygotski, L. S. (1998). Düşünce ve dil. Çev. S. Koray, İstanbul: Toplumsal Dönüşüm Yayınları, 2. Baskı. 